\title{
Benarkah Suku Bunga Memengaruhi Volatilitas Pasar Saham Syariah?
}

\author{
Septiana Indarwati \\ Program Pascasarjana, Universitas Islam Indonesia, Yogyakarta \\ septianaindar.wati@gmail.com
}

\author{
\begin{tabular}{l|l|l} 
Diterima: 14 April $2021 \quad$ Direvisi: 22 Juni $2021 \quad$ Dipublikasi: 28 Juni 2021
\end{tabular}
}

\begin{abstract}
This research attempts to explore to what extent the sensitivity volatility of Islamic stock markets in Indonesia toward macroeconomics. The writer examines inflation, exchange rates, money supply (JUB), interest rates (BIRATE), and Industrial Production Index (IPI) as part of the macroeconomic variables. Meanwhile, the writer also uses Jakarta Islamic Index (JII) as the measurements for Islamic stock markets. This research uses the calculation of the stock return volatility based on the Generalized Autoregressive Conditional Heteroscedasticity $(\operatorname{GARCH}(2,1))$ combined with Regressive Distributed Lag (ARDL) analysis. The writer uses monthly data from Indonesia Stock Exchange, starting from January 2006 to December 2019 as part of the data collection. This research found that BIRATE has a negative effect on the conventional stock market while the Islamic stock market has a positive and insignificant effect on the level $\alpha=5 \%$. It points out the Islamic principles that the interest rate is not a significant variable in explaining the stock market's volatility. According to the finding of this research, the writer argues that stabilizing interest rates will not significantly impact the volatility of the Islamic stock market.
\end{abstract}

Keywords: Exchange Rates; Industrial Production Index; Inflation; Interest Rates; Sharia Stock Markets

\begin{abstract}
Abstrak
Penelitian ini mencoba untuk mengeksplorasi sejauh mana sensitivitas volatilitas pasar saham syariah di Indonesia terkait dengan ekonomi makro. Penulis menggunakan inflasi, nilai tukar rupiah, penawaran uang (JUB), suku bunga (BI rate) dan Indeks Produksi Industri (IPI) sebagai pengukuran dari ekonomi makro. Sementara itu, penulis menggunakan Jakarta Islamic index (JII) sebagai pengukuran pasar saham syariah. Penelitian ini menggunakan perhitungan volatilitas return saham dengan Generalized Autoregressive Conditional Heteroskedasticity $\operatorname{GARCH}(2,1)$ dikombinasikan dengan Analisis Autoregressive Distributed Lag (ARDL). Pengumpulan data dalam penelitian ini menggunakan data bulanan dari Bursa Efek Indonesia dari bulan Januari 2006 sampai Desember 2019. Penelitian ini menemukan bahwa, variable BI Rate tidak berpengaruh signifikan terhadap pasar saham syariah pada taraf $\alpha=5 \%$. Ini menyoroti prinsip-prinsip Islam bahwa tingkat bunga bukanlah variabel yang signifikan dalam menjelaskan volatilitas pasar saham. Menurut temuan pada penelitian ini, penulis memberikan dukungan lebih lanjut bahwa menstabilkan suku bunga tidak akan berdampak signifikan pada volatilitas pasar saham syariah.
\end{abstract}

Kata Kunci: Indeks Produksi Industri; Inflasi; Nilai Tukar; Pasar Saham Syariah; Suku Bunga 


\section{PENDAHULUAN}

Pasar modal syariah telah berkembang selama lebih dari dua dekade, yaitu dimulai sejak pertama kali diluncurkannya reksa dana syariah pada tahun 1997. Sejak saat itu pasar modal terus tumbuh dan berkembang hingga saat ini. Tahun 2019 indeks syariah ISSI naik 2,03\% menjadi 187,7, indeks syariah JII naik 1,88\% menjadi 698,09 dan JII 70 naik sebesar 2,56\% menjadi 233,38. Peningkatan kapitalisasi pasar indeks syariah tahun 2019 meningkat untuk ISSI naik sebesar 2,13\% menjadi 3.744,82 triliun, JII naik 3,53\% menjadi 2.318,57 triliun.

Seiring perkembangan pengetahuan masyarakat tentang investasi syariah diiringi pertumbuhan pasar modal syariah yang meningkat, masyarakat (investor) membutuhkan suatu indikator yang penting untuk mengukur dan mengantisipasi kerugian terhadap instrumen atau aset keuangan seperti volatilitas. Volatilitas menggambarkan tingkat risiko yang dihadapi pemodal karena mencerminkan naik atau turunnya harga saham di bursa efek. Karena itu volatilitas sering digunakan sebagai penanda naik atau turunnya harga aset. Semakin tinggi volatilitas, maka semakin tinggi juga fluktuasi harga saham yang mungkin terjadi.

Bentuk investasi pada pasar modal berbasis syariah salah satunya Jakarta Islamic Index (JII). Perusahaan pasar modal di Indonesia PT. Danareksa Investment Management pada tanggal 3 juli 2000 menerbitkan Jakarta Islamic Index (JII) yang mempunyai tujuan yaitu sebagai acuan bagi para investor yang ingin menanamkan modalnya dengan prinsip syariah. Terdapat sebanyak 30 perusahaan yang tergabung dalam Jakarta Islamic Index (JII) untuk saat ini. Perhitungan JII di dalam pasar modal sendiri dilakukan oleh Bursa Efek Indonesia (BEI) dengan bobot kapitalisasi pasar besar.

Landasan berdasarkan asas kepatuhan syariah dalam penerbitan produk, pembuatan kontrak syariah, akad transaksi dagang, serta aktivitas alokasi aset lainnya. Berdasarkan Peraturan Otoritas Jasa Keuangan Nomor 35/POJK.04/2017 tentang Kriteria dan Penerbitan Daftar Efek Syariah tentang Kriteria Dan Penerbitan Daftar Efek Syariah dengan menentukan batas rasio keuangan secara kuantitatif yang harus dipatuhi setelah steril dari aturan kualitatif adalah total utang yang berbasis bunga dibandingkan dengan total aset tidak lebih dari 45 persen, dan total pendapatan bunga dan pendapatan tidak halal (haram) lainnya dibandingkan dengan total pendapatan usaha dan pendapatan lain-lain tidak lebih dari 10 persen (Amanah et al., 2019).

Pergerakan volatilitas return saham pada indeks harga saham Jakarta Islamic Index (JII) keduanya mengalami pergerakan cukup besar terutama pada tahun 2008 dan 2020 terlihat kontras. Pada tahun 2000 cenderung mengalami volatilitas normal sampai pada tahun 2008 harga indeks JII dibuka sebesar 476.97 dengan penutupan di tahun 2008 sebesar 216.19. Hal ini diasumsikan, di tahun 2008 terdapat shock yang disebabkan oleh krisis global. Tahun 2013 diakibatkan dari krisis depresiasi mata uang rupiah, tahun 2015 diakibatkan oleh melambatnya pertumbuhan perekonomian di 
Indonesia yang hanya mencapai 4,79 . Selanjutnya tahun 2020 yang diakibatkan dari pandemi Covid-19 seperti yang tergambar pada Gambar 1.

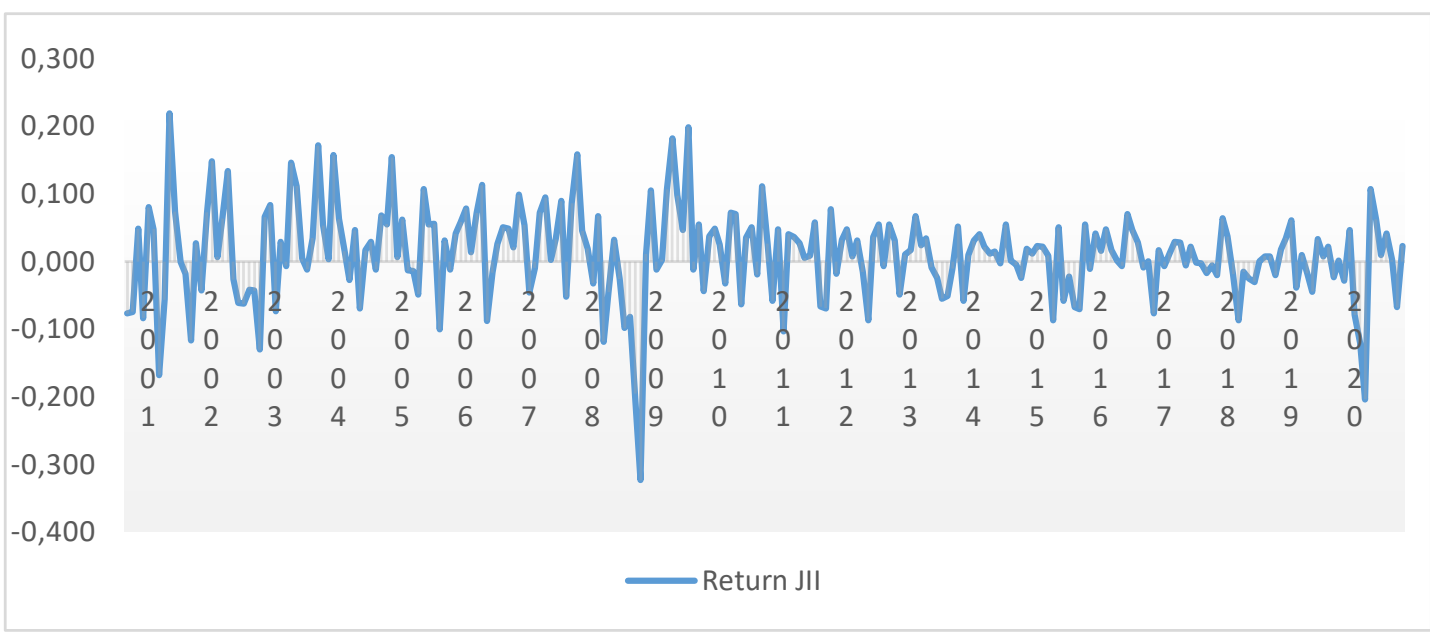

Gambar 1. Return JII 2001:M1 hingga 2020:M10

Sumber: Bursa Efek Indonesia, Data Diolah Tahun 2001-2000

Dampak yang terjadi akibat volatilitas yang cukup besar pada return saham dapat mengakibatkan risiko yang cukup besar pula untuk para investor, karena investasi tersebut bisa jadi dapat merugikan. Pasang surutnya volatilitas pasar saham diindikasikan oleh beberapa faktor baik faktor permintaan maupun penawaran, faktor teknikal maupun faktor fundamental. Faktor fundamental mencakup variabel makroekonomi dan pertumbuhan industri. Oleh sebab itu, kondisi perekonomian makro yang stabil mendorong pasar saham yang stabil pula. Kestabilan perekonomian Negara dapat dicerminkan dari kestabilan pasar saham baik pasar saham syariah maupun konvensional menurut (Ardana, 2016a) Indikator variabel ekonomi makro dan moneter yang seringkali dihubungkan dengan pasar saham adalah jumlah uang beredar (JUB), fluktuasi tingkat suku bunga bank Indonesia, inflasi, kurs rupiah, dan Indeks Produksi Industri (IPI).

Penelitian ini bertujuan untuk mengeksplorasi tingkat sensitivitas volatilitas pasar saham syariah di Indonesia terkait dengan ekonomi makro. Novelty pada penelitian ini adalah penggunaan variabel inflasi, nilai tukar rupiah, penawaran uang, suku bunga, dan Indeks Produksi Industri sebagai pengukuran dari ekonomi makro. Selain itu, penelitian ini menggunakan perhitungan volatilitas return saham dengan Generalized Autoregressive Conditional Heteroskedasticity $\operatorname{GARCH}(2,1)$ yang dikombinasikan dengan Analisis Autoregressive Distributed Lag (ARDL). Temuan penelitian ini diharapkan berkontribusi secara teoritis dan praktis dalam mengembangkan pengelolaan keuangan syariah, khususnya pada instrumen saham syariah. 


\section{TINJAUAN PUSTAKA}

Teori yang menjelaskan tentang hubungan volatilitas pasar saham dan ekonomi di antaranya model nilai diskonto sederhana (Simple Discounted Present Value Model/SDPVM), model harga aset modal (Capital Asset Pricing Model/CAPM) dan teori harga arbitrage (Arbitrage Pricing Theory/APT). Menurut SDPVM, harga saham ditentukan oleh arus kas masa depan ke perusahaan dan tingkat diskonto. Dua faktor ini dapat dipengaruhi oleh variabel makroekonomi dan nantinya akan memengaruhi volatilitas pasar saham (Yusof et al., 2007). Ini menyiratkan bahwa perubahan dalam tingkat ketidakpastian tentang kondisi ekonomi makro di masa depan akan mengakibatkan perubahan volatilitas return saham dengan asumsi bahwa tingkat diskonto akan konstan.

Dampak dari variable-variabel ekonomi makro dapat dianalisis lebih lanjut dengan cara penghitungan harga ekuitas pada suatu titik waktu sama dengan nilai sekarang dan perkiraan arus kas masa depan (termasuk capital gain dan dividen) kepada pemegang saham.

$$
E_{t-1} Q_{t}^{i}=E_{t-1} \sum_{k-1}^{\infty} \frac{C_{t+k}^{i}\left(X_{t+k}\right)}{\left(1+R_{t+k}\right)^{k}}
$$

Di mana $Q_{t}^{i}$ adalah harga dari aset I pada waktu t, $C_{t+k}^{i}$ menunjukkan arus kas yang terkait dengan aset i, $R$ menunjukkan tingkat bunga dan $E_{t-1}$ adalah operator ekspektasi. Dalam ekonomi terbuka dan sistem perekonomian di Indonesia, arus kas perusahaan $C_{t+k}^{i}$ dipengaruhi perkembangan perubahan variabel-variabel ekonomi makro, X. Contoh $\mathrm{X}$ adalah jumlah uang beredar (JUB), tingkat suku bunga Bank Indonesia (BI rate), nilai tukar (kurs), inflasi dan output riil (IPI).

Variabel penelitian ini menggunakan Indeks Produksi Industri (IPI), Jumlah Uang Beredar (JUB), suku bunga Bank Indonesia (BIRATE), dan nilai tukar (kurs) sebagai indikator variabel ekonomi makro untuk mengukur dampak sensitivitas volatilitas pasar saham (Ardana, 2016; Ash-Shidiq \& Setiawan, 2015; Inflasi \& Bunga, n.d.; Yusof et al., 2007).

Volatilitas harga saham Indonesia dan Malaysia menggunakan Model $\mathrm{ARCH} / \mathrm{GARCH}$ untuk mengestimasi volatilitas. Hasil penelitian juga menunjukkan nilai $\alpha$ kedua indeks harga saham menunjukkan nilai yang lebih besar dari 0,7. Hal ini berarti para investor harus hati-hati dalam melakukan investasi karena volatilitas yang terjadi pada kedua indeks adalah tinggi dan berlangsung terusmenerus, untuk kembali normal peluangnya kecil (Kartika et al., 2010). Penelitian ini mengembangkan penelitian yang sudah ada dengan menganalisis hubungan dengan variabel ekonomi makro.

Penelitian ini mengembangkan penelitian pada tahun 2007 dengan judul Stock Market Volatility Transmission in Malaysia: Islamic Versus Conventional Stock Market. Di antara variabel kebijakan moneter yang diuji dalam penelitian ini adalah jumlah uang beredar (M1) dan (M2), suku bunga (TBR), nilai tukar (MYR), dan Indeks Produksi Industri (IPI). Selain itu, Kuala Lumpur Composite Index (KLCI) dan Rashid 
Hussain Berhad Islamic Index (RHBII) juga digunakan dalam penelitian ini. Studi ini menemukan bahwa volatilitas tingkat bunga memengaruhi volatilitas pasar saham konvensional tetapi tidak memengaruhi volatilitas pasar saham syariah di Malaysia (Yusoff et al., 2007). Perbedaan pada penelitian tersebut terletak pada studi kasus negara Malaysia dengan negara Indonesia, variabel suku bunga SBI, uang beredar, inflasi dan nilai tukar terhadap indeks harga saham Jakarta Islamic index (JII) (AshShidiq \& Setiawan, 2015).

Penelitian ini memperbaharui penelitian yang dilakukan oleh (Ardana, 2016a) yang berjudul Pengaruh Variabel Makroekonomi terhadap Indeks Saham Syariah di Indonesia. Model penelitian analisis Error Correction Model (ECM) dengan variabel nilai tukar rupiah, inflasi, suku bunga bank Indonesia (BI rate), harga minyak dunia dan Sertifikat Bank Indonesia (SBIS). Penelitian ini bertujuan untuk menganalisis pengaruh makroekonomi terhadap indeks saham syariah Indonesia dengan hasil akhir yaitu mengukur pengaruh variabel ekonomi makro terhadap indeks saham syariah Indonesia dalam jangka pendek dan jangka panjang. Hubungan jangka pendek terhadap indeks saham syariah hanya terjadi pada nilai tukar dan SBIS, sedangkan hubungan jangka panjang terhadap indeks saham syariah adalah tingkat suku bunga, SBIS dan harga minyak dunia (Ardana, 2016a). Pengembangan terletak pada pemeliharaan alat analisis dengan menggunakan autoregressive distributed lag.

Penelitian lainnya berjudul Pengaruh Inflasi, Suku Bunga, Kurs, dan Pertumbuhan PDB terhadap Indeks Harga Saham Gabungan. Penelitian ini menggunakan alat analisis regresi berganda untuk menganalisis suku bunga sertifikat bank Indonesia, tingkat inflasi, tingkat pertumbuhan GDP dan kurs terhadap IHSG di Bursa Efek Indonesia. Temuan pada penelitian ini menunjukkan bahwa hanya kurs yang berpengaruh secara signifikan terhadap IHSG, sedangkan tingkat inflasi, suku bunga SBI dan pertumbuhan PDB tidak berpengaruh terhadap IHSG (Inflasi \& Bunga, n.d). Penelitian ini menindaklanjuti penelitian yang dilakukan oleh (Kewal, 2012) dengan membedakan variabel dependen dari IHSG ke JII dan mengembangkan penelitian (Ardana, 2016a) dan (Ash-Shidiq \& Setiawan, 2015) dengan menggunakan alat analisis Autoregressive Distributed Lag (ARDL).

\section{METODE PENELITIAN}

Penelitian ini memiliki populasi yaitu Jakarta Islamic Index (JII) dan LQ45 dengan Periode sampel selama 1 Januari 2006 - 31 Desember 2019 menggunakan data time series sebanyak 168 bulan pengamatan. Variabel penelitian ini menggunakan Indeks Produksi Industri (IPI), Jumlah Uang Beredar (JUB), Suku Bunga Bank Indonesia (BI Rate), dan Nilai Tukar (kurs) sebagai indikator variabel ekonomi makro untuk mengukur dampak sensitivitas volatilitas pasar saham seperti pada penelitian terdahulu (Ardana, 2016; Ash-Shidiq \& Setiawan, 2015).

Teknik analisis data menggunakan alat analisis Generalized Autoregressive Conditional Heteroskedasticity (GARCH) dan Autoregressive Distributed Lag (ARDL) 
dengan masing-masing kegunaan sebagai alat analisis volatilitas pasar saham syariah dan untuk membedakan respons jangka pendek dan jangka panjang dari variabel ekonomi makro terhadap satu unit perubahan dalam variabel pasar saham syariah dengan bantuan software eviews 10 .

\section{Generalized Autoregressive Conditional Heteroscedasticity (GARCH)}

Perhitungan volatilitas pasar saham konvensional dan pasar saham syariah menggunakan Generalized Autoregressive Conditional Heteroskedasticity (GARCH). Untuk menjelaskan model GARCH menggunakan regresi sederhana sebagai berikut (Widarjono A., 2020):

$$
\ln (Y)_{t}=\varphi_{0}+\ln (Y)_{t-1}+e_{t}
$$

Sedangkan varian residual nya dengan model GARCH sebagai berikut:

$$
\sigma_{t}^{2}=\alpha_{0}+\alpha_{1} e_{t-1}^{2}+\lambda_{1} \sigma_{t-1}^{2}
$$

Di mana $\mathrm{Y}$ adalah VJII dan $\sigma_{t}^{2}$ adalah kondisional variansi. Pemodelan volatilitas untuk beberapa proses yaitu $\operatorname{GARCH}(1,1), \operatorname{GARCH}(1,2), \operatorname{GARCH}(2,1), \operatorname{GARCH}(2,2)$ untuk residual dengan kondisional mean berupa konstanta $\mathrm{C}$ ditambah komponen error, di mana komponen error diasumsikan berdistribusi normal, dinyatakan dengan persamaan sebagai berikut:

1. $\operatorname{GARCH}(1,1)$

$$
\sigma_{t}^{2}=\alpha_{0}+\alpha_{1} e_{t-1}^{2}+\lambda_{1} \sigma_{t-1}^{2}
$$

2. $\operatorname{GARCH}(1,2)$

$$
\sigma_{t}^{2}=\alpha_{0}+\alpha_{1} e_{t-1}^{2}+\lambda_{1} \sigma_{t-1}^{2}+\lambda_{2} \sigma_{t-2}^{2}
$$

3. $\operatorname{GARCH}(2,1)$

$$
\sigma_{t}^{2}=\alpha_{0}+\alpha_{1} e_{t-1}^{2}+\alpha_{2} e_{t-2}^{2}+\lambda_{1} \sigma_{t-1}^{2}
$$

4. $\operatorname{GARCH}(2,2)$

$$
\sigma_{t}^{2}=\alpha_{0}+\alpha_{1} e_{t-1}^{2}+\alpha_{2} e_{t-2}^{2}+\lambda_{1} \sigma_{t-1}^{2}+\lambda_{2} \sigma_{t-2}^{2}
$$

\section{Auto-Regressive Distributed lag (ARDL)}

Hubungan antara variabel dependen volatilitas return harga saham Jakarta Islamic index (JII) dan LQ45 dengan variabel independen berupa inflasi, kurs, jumlah uang beredar, BI rate, dan IPI dinyatakan dalam persamaan sebagai berikut:

$$
V J I I=f(I N F L A S I, K U R S, J U B, B I \text { rate }, I P I)
$$

Di mana VJII adalah volatilitas harga saham Jakarta Islamic Index (JII) pada persamaan (8) dipengaruhi oleh variabel ekonomi makro dapat dinyatakan dalam persamaan regresi sebagai berikut:

$V_{J I I}=\beta_{O}+\beta_{1} I I N F L A S I_{t}+\beta_{2}$ KURS $_{t}+\beta_{3} \log (J U B)_{t}+\beta_{4} B I$ rate $_{t}+\beta_{5} I P I_{t}+\varepsilon_{t}$ 
Variabel ekonomi makro meliputi inflasi yaitu inflasi bulanan yang dihitung dengan menggunakan indeks harga konsumen (\%). Kurs adalah rata-rata bulanan Rupiah (IDR) terhadap Dolar AS (IDR per US \$). JUB adalah Jumlah uang beredar secara keseluruhan (Miliar IDR). BI Rate adalah suku bunga bank Indonesia bulanan (\%) dan IPI adalah indeks produksi industri bulanan (\%).

Inflasi merupakan kenaikan harga secara keseluruhan dan dapat memengaruhi kegiatan perekonomian seperti pada investasi maupun harga saham. Inflasi yang relatif tinggi dapat memberikan sinyal negatif bagi pemodal di pasar modal. Inflasi yang tinggi diikuti dengan suku bunga menyebabkan pengurangan terhadap tingkat investasi (Ash-Shiddiqy, 2019; Ash-Shidiq \& Setiawan, 2015; Karim et al., 2020; Karyatun et al., 2021; Putra et al., n.d.; Taufiq et al., n.d.). Nilai tukar (kurs) merupakan sebuah selisih antara mata uang domestik dengan mata uang asing. Perubahan kurs yang melemah memberikan dampak yang negatif terhadap pasar modal khususnya saham yang di mana memberikan dampak juga terhadap pasar ekuitas yang tidak menarik lagi untuk para investor (Ash-Shiddiqy, 2019; Ash-Shidiq \& Setiawan, 2015; Yusuf \& Hamzah, n.d.; Karim et al., 2020b; Khan, 2018). Jumlah uang yang beredar dalam suatu negara dikenal dengan JUB. Pertumbuhan jumlah uang beredar yang wajar dapat memberikan pengaruh positif terhadap perekonomian dan pasar ekuitas di suatu Negara dalam jangka yang relatif pendek. Empirical Evidence on the Relationship between Stock Market Volatility and Macroeconomics Volatility in Malaysia dengan hasil bahwa hubungan harga saham berhubungan positif signifikan dengan penawaran uang (jumlah uang beredar) (Zakaria, 2012). Suku bunga Bank Indonesia (BI rate) mempunyai fungsi yang dapat memberikan perubahan variabel makroekonomi yang lain, contohnya inflasi dan nilai tukar rupiah. Kenaikan suku bunga dapat menyebabkan peningkatan biaya peluang memegang uang yang dapat menyebabkan perubahan diversifikasi portofolio antara saham dan sekuritas yang berbunga sebagai akibat dari penurunan harga saham (Khan, 2018). IPI dalam pasar modal Indonesia terdiri atas pergerakan saham di BEI yang tergabung dalam suatu indeks yang dinamakan IPI. Membaiknya IPI dalam pasar modal mencerminkan kondisi ekonomi industri. Indeks produksi industri dan harga saham berhubungan positif karena kenaikan IPI menyebabkan peningkatan produksi sektor industri yang berdampak pada peningkatan keuntungan industri dan korporasi. Seiring dengan kenaikan dividen yang mengakibatkan kenaikan harga saham maka ditemukan hubungan positif antara IPI dan harga saham (Ash-Shiddiqy, 2019; Khan, 2018).

Tabel 1. Definisi dan Hipotesis

\begin{tabular}{lll}
\hline \multicolumn{1}{c}{ Variable } & \multicolumn{1}{c}{ Definition } & hypothesized sign \\
\hline \multicolumn{1}{c}{ Dependent Variable } & \multicolumn{1}{c}{} \\
\hline VIII & $\begin{array}{l}\text { Volatilitas dari Return Harga Saham } \\
\text { JII. Untuk mengukur volatilitas } \\
\text { ketidakstabilan harga saham } \\
\text { syariah }\end{array}$ \\
\hline
\end{tabular}




\begin{tabular}{llc}
\hline Variable & Definition & hypothesized sign \\
\hline $\begin{array}{l}\text { Independent Variable } \\
\text { Variabel ekonomi makro }\end{array}$ & & \\
\hline Inflasi & $\begin{array}{l}\text { Perubahan harga (\%) Untuk } \\
\text { mengukur kenaikan harga secara } \\
\text { agregat }\end{array}$ & - \\
\hline Kurs & $\begin{array}{l}\text { Nilai tukar rupiah terhadap dolar } \\
\text { (Rp) }\end{array}$ & - \\
\hline JUB & $\begin{array}{l}\text { Jumlah uang beredar (Rp) untuk } \\
\text { mengukur Penawaran uang }\end{array}$ & + \\
\hline BI Rate & Suku bunga bank Indonesia (\%). & - \\
\hline IPI & $\begin{array}{l}\text { Indeks produksi industri (\%). Untuk } \\
\text { mengukur output riil }\end{array}$ & + \\
\hline
\end{tabular}

Selanjutnya, dalam melakukan analisis, persamaan 2 diformulasikan dengan menggunakan ARDL sebagai berikut:

$$
\begin{aligned}
\Delta \text { JII }_{t}=\alpha_{0}+ & \alpha_{1} \text { VJII I }_{t-1}+\alpha_{2} \text { INFLASI }_{t-1}+\alpha_{3} \text { KURS }_{t-1}+\alpha_{4} \log \log (J U B)_{t-1} \\
& +\alpha_{5} \text { BI RATE }_{t-1}+\alpha_{6} I P I_{t-1}+\sum_{1=1}^{n} \gamma_{1 i} \Delta J I I_{t-1} \\
& +\sum_{1=1}^{n} \gamma_{2 i} \Delta I N F L A S I_{t-1}+\sum_{1=1}^{n} \gamma_{3 i} \Delta K U R S_{t-1} \\
& +\sum_{1=1}^{n} \gamma_{4 i} \Delta \log \log (J U B)_{t-1}+\sum_{1=1}^{n} \gamma_{5 i} \Delta B I R A T E_{t-1} \\
& +\sum_{1=1}^{n} \gamma_{6 i} \Delta I P I_{t-1}+\varepsilon_{t}
\end{aligned}
$$

Di mana $\Delta$ ditunjukkan untuk first difference variabel, $\alpha_{0}$ adalah konstanta, $\alpha_{1}$ adalah persamaan perkalian jangka panjang (long run). Koefisien estimasi satu sampai enam $\left(\gamma_{1 i}-\gamma_{6 i}\right)$ mengindikasikan hubungan jangka pendek dan koefisien estimasi satu sampai enam $\left(\tau_{1 i}-\tau_{6 i}\right)$ mengindikasikan hubungan dinamika jangka pendek (short run) pada metode Autoregressive Distributed Lag.

\section{Uji Stasioneritas Data}

Pengujian data stasioneritas ataupun tidak stasioner menggunakan pengujian akar unit. Uji akar unit yang biasa digunakan untuk mengetahui ada tidaknya akar unit adalah uji Augmented Dickey-Fuller dan uji Phillips-Perron. Keduanya mengindikasikan keberadaan akar unit sebagai hipotesis null. Uji akar unit Augmented Dickey-Fuller yang diperkenalkan oleh Dickey dan Fuller merupakan suatu uji formal untuk menstasionerkan data yang dikenal dengan "Unit Root Test" atau uji akar unit. Untuk memudahkan pengertian mengenai unit root, dapat

dijelaskan dengan model sebagai berikut: 


$$
Y_{t}=\rho Y_{t-1}+U_{t}
$$

Koefisien $\rho$ bernilai 0 dan hipotesis ditolak sehingga model menjadi stasioner. Hipotesis yang digunakan pada pengujian Augmented Dickey-Fuller yaitu:

1. $H_{0}$ diterima jika $\rho>$ nilai statistik DF (Dickey-Fuller) artinya Yt mempunyai akar unit atau Yt tidak stasioner.

2. $\quad H_{0}$ ditolak jika $\rho<$ nilai statistik DF (Dickey-Fuller) artinya Yt tidak mempunyai akar unit atau Yt stasioner.

\section{Uji Kointegrasi}

Selanjutnya tahapan uji kointegrasi menggunakan: bound test, tahap ini dilakukan agar peneliti dapat mengetahui apakah terdapat hubungan jangka panjang antar variable VJII terhadap variabel Indeks Produksi Industri (IPI), Jumlah Uang Beredar (JUB), Suku Bunga Bank Indonesia (BI Rate), dan Nilai Tukar (kurs).

Hipotesis nol adalah tidak ada kointegrasi menolak adanya kointegrasi. Hipotesis nol dari tidak adanya kointegrasi adalah sebagai berikut:

$$
\begin{aligned}
& H_{0}: \beta_{1}=\beta_{2}=\beta_{3}=\beta_{4}=\beta_{5}=\beta_{6}=\beta_{7} \\
& H_{a}: \beta_{1} \neq \beta_{2} \neq \beta_{3} \neq \beta_{4} \neq \beta_{5} \neq \beta_{6} \neq \beta_{7}
\end{aligned}
$$

Uji Kointegrasi: Bound Test, hipotesis tersebut dilakukan dengan membandingkan nilai $\mathrm{F}$ dengan nilai kritis pesaran. Pesaran memberikan nilai kritis uji kointegrasi yang meliputi batas bawah I (0) dan batas atas I (1). Kointegrasi terjadi antara variabel independen dan dependen ketika nilai F hitung melebihi I (1). Namun, ketika nilai F hitung kurang dari I (0) kointegrasi tidak ada. Sedangkan nilai F hitung antara I (0) dan I (1) maka tidak ada keputusan tentang kointegrasi.

Persamaan (10) diformulasikan dengan menggunakan Error Correction Model (ECM) sebagai berikut:

$$
\begin{aligned}
\Delta V J I I_{t}=\varphi_{0} & +\sum_{1=1}^{r} \varphi_{1 i} \Delta J I I_{t-1}+\sum_{1=1}^{r} \varphi_{2 i} \Delta I N F L A S I_{t-1}+\sum_{1=1}^{r} \varphi_{3 i} \Delta K U R S_{t-1} \\
& +\sum_{\substack{1=1 \\
r}}^{r} \varphi_{4 i} \Delta \log \log (J U B)_{t-1}+\sum_{1=1}^{r} \varphi_{5 i} \Delta B I R A T E_{t-1} \\
& +\sum_{1=1}^{r} \varphi_{6 i} \Delta I P I_{t-1}+\varphi_{7 i} E C T_{t}+\varepsilon_{t}
\end{aligned}
$$

\section{Uji Asumsi Klasik Autokorelasi}

Uji asumsi klasik autokorelasi menguji korelasi variabel gangguan antara variabel dependen dan variabel independen pada periode tertentu dengan periode yang lain dengan kata lain variabel gangguan tidak random. Dalam data time series pengujian menggunakan autokorelasi sangat dibutuhkan sebab, masalah autokorelasi hampir dipastikan terdapat pada data time series. Untuk mengetahui 
terdapat autokorelasi dalam sebuah variabel dilakukan uji breusch-godfrey atau LM test. Hasil dapat diinterpretasikan dengan membandingkan besar nilai X2 hitung (Obs*R-square) dan nilai $\mathrm{X} 2$ tabel (Chi square pada $\alpha=5 \%$ dengan $\mathrm{DF}=\mathrm{K}$ ) (Widarjono, 2020). Perumusan hipotesis yang digunakan adalah:

1. $H_{0}: \rho \neq 0$ ada masalah autokorelasi

2. $H_{a}: \rho=0$ tidak ada masalah autokorelasi

\section{HASIL DAN PEMBAHASAN}

Pengolahan data pada penelitian ini menggunakan program eviews 10 , dengan menggunakan data runtut waktu (time series) dimulai dari Januari tahun 2006 sampai dengan Desember 2019. Berdasarkan Tabel 2 statistik deskriptif dijabarkan jumlah data observasi sebanyak 168 data. Nilai return JII (Jakarta Islamic Index) memiliki nilai return maksimum sebesar 787.12 dan yang minimum sebesar 193.68. Nilai mean (rata-rata) return sebesar 544.83 lebih kecil dari standar deviasi yaitu sebesar 160.84 mengartikan bahwa, data yang digunakan dalam variabel Jll mempunyai sebaran yang tidak besar atau memiliki kesenjangan yang cukup kecil sehingga penyimpangan data dikatakan baik atau merata.

Tabel 2. Statistik Deskriptif

\begin{tabular}{ccccccc}
\hline Variabel & Satuan & Mean & Maximum & Minimum & Std.Dev & Observasi \\
\hline JII & IDR & 544.83 & 787.12 & 193.68 & 160.84 & 168 \\
VIII & Log & 0.007448 & 0.180941 & -0.180941 & 0.062010 & 168 \\
BIRATE & $\%$ & 6.99 & 12.750 & 4.25 & 1.86 & 168 \\
INFLASI & $\%$ & 5.93 & 17.92 & 2.27 & 3.22 & 168 \\
IPI & $\%$ & 123.63 & 158.02 & 92.32 & 13.77 & 168 \\
JUB & Milyar & 4196674. & 7701910. & 1468110 & 1899337. & 168 \\
KURS & IDR/\$ & 11193.11 & 15232.00 & 8508.00 & 2101.27 & 168 \\
\hline
\end{tabular}

Sumber: Hasil Data Diolah Eviews 10

BI Rate terendah pada bulan September 2017 sampai bulan April tahun 2018, sedangkan tertinggi jatuh pada bulan Januari - April tahun 2006 sebesar 12.75\%. Pada tahun yang sama inflasi dan BI Rate memiliki nilai tertinggi karena $\mathrm{BI}$ rate sebagai senjata pemerintah dalam kebijakan moneter sebagai pengendalian jumlah uang beredar dan BI Rate dapat diturunkan guna menjaga stabilitas sistem keuangan negara seperti pengendalian inflasi.

Dari Tabel 2, tercatat standar deviasi pada VJII sebesar 0.062010. Angka ini mengindikasikan bahwa semakin kecil standar deviasi nilai-nilai pada sampel data cenderung dekat dengan nilai reratanya ini menggambarkan variasi dari VJII lebih sedikit. 
Selanjutnya, Tabel 3 menjabarkan estimasi dan signifikansi model $\operatorname{GARCH}(2,1)$. Secara sistematis model return pasar saham syariah (JII) dari persamaan (6) dapat ditulis sebagai berikut:

Pasar Saham Syariah (JII) GARCH $(2,1)$

$$
\sigma_{t}^{2}=4.37 E-05_{0}+0.413761 e_{t-1}^{2}+\left(-0.366453 e_{t-2}^{2}\right)+0.934493 \sigma_{t-1}^{2}
$$

Model tersebut memberikan informasi tentang pola volatilitas return pasar saham JII pada periode januari 2006 sampai dengan desember 2019. Model ini menunjukkan pergerakan pasar saham JII dipengaruhi oleh besarnya volatilitas pada dua bulan sebelumnya, dan varian harga satu bulan sebelumnya. Jumlah koefisien adalah 0.981801 untuk pasar saham syariah memiliki nilai koefisien kurang dari satu karena itu memenuhi non-eksplosif dari varian bersyarat.

Tabel 3. Estimasi dan Signifikansi Model GARCH $(2,1)$

\begin{tabular}{|c|c|c|c|c|}
\hline Saham & Model & Parameter & Estimasi & P-Value \\
\hline & \multicolumn{4}{|c|}{ Pasar Saham Likelihood as Syariah } \\
\hline & & $\alpha_{0}$ & 0.413761 & 0.0002 \\
\hline & $\operatorname{GARCH}(2,1)$ & $\alpha_{2}$ & -0.366453 & 0.0013 \\
\hline & & $\lambda_{1}$ & 0.934493 & 0.0000 \\
\hline \multirow[t]{4}{*}{ JII } & & Skewness & -0.649799 & \\
\hline & & Kurtosis & 3.684559 & \\
\hline & $\mathrm{ARCH} L \mathrm{M}$ & F-stats & 0.247073 & 0.9953 \\
\hline & & Observed-R & 3.168717 & 0.9942 \\
\hline
\end{tabular}

Sumber: Hasil Data Diolah Eviews 10

Grafik volatilitas yang ditunjukkan oleh Gambar 2 dapat menjelaskan bahwa potensi risiko baik indeks syariah maupun konvensional tersebut berubah sesuai dengan waktu. Ketidakstabilan yang sangat tinggi ini dilihat dari nilai CSD pada periode tersebut yang lebih tinggi dibandingkan dengan CSD pada periode lainnya. $\mathrm{Hal}$ ini disebabkan adanya faktor-faktor ekonomi ataupun ketidakstabilan ekonomi seperti inflasi, BI rate, IPI, JUB dan kurs. Volatilitas pada indeks JII terjadi antara tahun 2008-2009 yang terjadi akibat krisis finansial terburuk dalam 80 tahun terakhir, bahkan para ekonom dunia menyebutnya sebagai the mother of all crises (Sugema, 2014). 


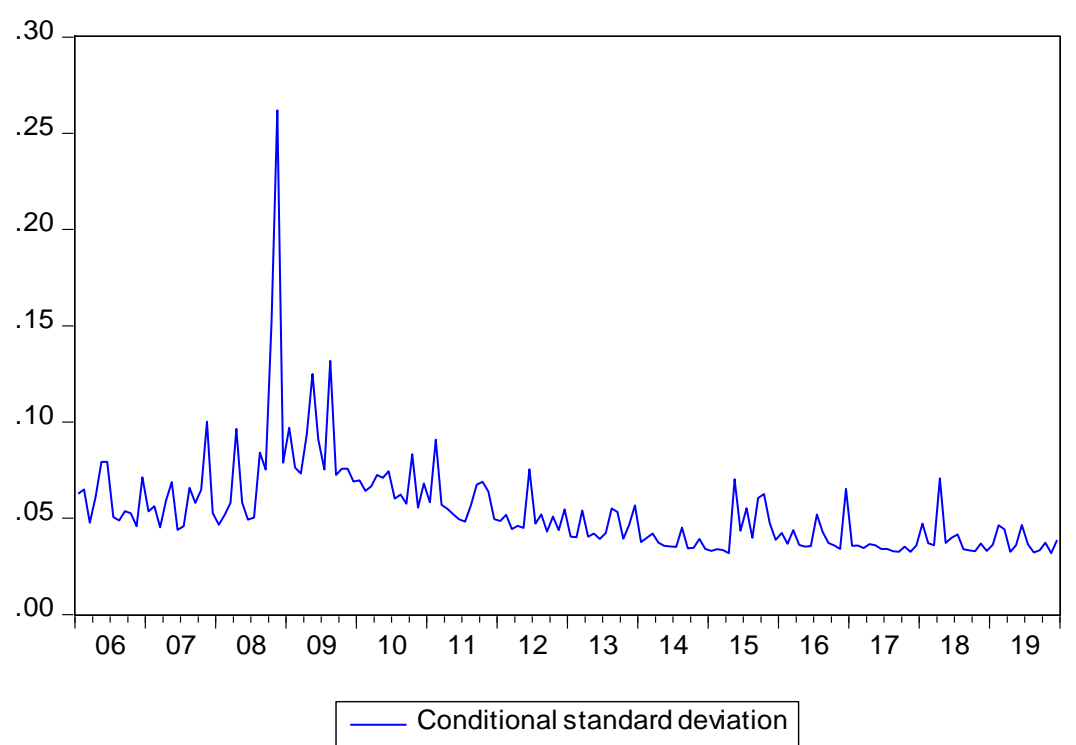

Gambar 2. Plot Volatilitas Indeks JII

Sumber: Hasil Data Diolah Eviews 10

Ditunjukkan pada Tabel 4 uji stasioneritas menggunakan Augmented DickeyFuller (ADF) dan Phillips-Perron (PP) kedua test tersebut mencakup Constant, Constant and Trend dan menggunakan Akaike Info Criterion (AIC) untuk memilih lag yang optimal untuk uji ADF. Volatilitas JII (VJII),), BI-rate, inflasi dan log JUB (LUB) stasioner pada derajat level. IPI dan kurs tidak stasioner pada data level namun variabel tersebut stasioneritas pada data derajat pertama (first difference). Dengan kesimpulan bahwa semua variabel berada pada I (1) dan tidak ada pada I (2). Pengujian ini menegaskan bahwa model ARDL merupakan model yang pantas dan sesuai dalam memperkirakan volatilitas saham syariah dan konvensional pada Bursa Efek Indonesia dalam satu periode tertentu.

Tabel 4. Augmented Dickey-Fuller dan Philips-Perron Unit Roots test

\begin{tabular}{|c|c|c|c|c|c|c|c|c|}
\hline \multirow{3}{*}{ Variable } & \multicolumn{4}{|c|}{ Level data } & \multicolumn{4}{|c|}{ First difference data } \\
\hline & \multicolumn{2}{|c|}{ Constant } & \multicolumn{2}{|c|}{ Constant and Trend } & \multicolumn{2}{|c|}{ Constant } & \multicolumn{2}{|c|}{ Constant and Trend } \\
\hline & ADF & PP & ADF & PP & ADF & PP & ADF & PP \\
\hline VJII & $-10.06 * * *$ & $-10.20 * * *$ & $-10.10 * * *$ & $-10.22 * * *$ & $-15.91 * * *$ & $-36.15^{* * *}$ & $-15.86 * * *$ & $-36.04 * * *$ \\
\hline BI Rate & $-3.37 * *$ & $-2.97 * *$ & $-3.67 * *$ & -2.86 & $-4.82 * * *$ & $-6.92 * * *$ & $-4.96 * * *$ & $-7.09 * * *$ \\
\hline Inflasi & $-4.07 * * *$ & $-3.43^{* *}$ & $-4.40 * * *$ & $-3.62^{* *}$ & $-4.07 * * *$ & $-9.80 * * *$ & $-9.78 * * *$ & $-9.86 * * *$ \\
\hline IPI & -0.61 & -1.37 & -1.26 & -2.46 & $-13.22 * * *$ & $-21.96 * * *$ & $-13.24 * * *$ & $-21.99 * * *$ \\
\hline LJUB & $-2.78^{*}$ & $-7.47 * * *$ & 0.35 & -0.98 & -1.33 & $-15.97^{* * *}$ & -1.33 & $-15.97 * * *$ \\
\hline Kurs & -0.72 & -0.74 & -2.23 & -2.34 & $-12.61 * * *$ & $-12.61 * * *$ & $-12.58 * * *$ & $-12.57 * * *$ \\
\hline
\end{tabular}

Catatan: $* * * * * ; *$ adalah stasioner pada $\alpha=1 \%, 5 \%, 10 \%$

Sumber: Hasil Data Diolah Eviews 10 
Hasil evaluasi ARDL untuk pasar saham syariah berada pada Tabel 5 dengan hasil $R$-squared sebesar 0.418162 yang menerangkan bahwa variabel pasar saham syariah (JII) mampu menjelaskan variabel inflasi, kurs, JUB, BI rate, dan IPI sebesar $41,81 \%$ sedangkan sisanya sebesar $58,19 \%$ dijelaskan variabel lain di luar model. Begitu pula dengan variabel pasar saham konvensional sebesar 0.450409 yang menerangkan bahwa variabel pasar saham syariah (JII) mampu menjelaskan variabel inflasi, kurs, JUB, BI rate, dan IPI sebesar $45.04 \%$ sedangkan sisanya sebesar $54,96 \%$ dijelaskan variabel lain di luar model.

Berdasarkan pada Tabel 5 hasil uji kelayakan F-statistic model dilakukan dengan eviews 10. Data pada variabel pasar saham konvensional menghasilkan nilai $F$ statistic lebih besar dari F-table sebesar $14.29632>2.27$ dengan tingkat signifikan sebesar $0.000000<1 \%$ karena itu $H_{0}$ tidak dapat diterima dengan artian sesuai dengan hipotesis maka variabel inflasi, kurs, JUB , BI rate, dan IPI berpengaruh signifikan terhadap variabel indeks harga saham konvensional.

Tabel 5. Hasil Estimasi Model ARDL Persamaan Pasar Saham Syariah

\begin{tabular}{lccc}
\hline \multicolumn{1}{c}{ Variabel } & Coefisien & Std.Error & t-Statistik \\
\hline C & Pasar Saham Syariah & & \\
JII(-1) & $0.829930^{*}$ & 0.477562 & 1.737848 \\
BI Rate & -0.005437 & 0.068153 & -0.079783 \\
BI Rate(-1) & -0.037623 & 0.022016 & -1.708879 \\
INFLASI & $0.040518^{*}$ & 0.021107 & 1.919680 \\
IPI & $-0.006567^{* *}$ & 0.002519 & -2.607171 \\
IPI(-1) & $-9.05 \mathrm{E}-05$ & 0.000710 & -0.127564 \\
KURS & $-0.001214^{*}$ & 0.000734 & -1.655001 \\
KURS(-1) & $-9.55 \mathrm{E}-05^{* * *}$ & $1.34 \mathrm{E}-05$ & -7.143997 \\
LUB & $0.000108^{* * *}$ & $1.29 \mathrm{E}-05$ & 8.332033 \\
R-squared & -0.051532 & 0.031785 & -1.621283 \\
\hline
\end{tabular}

\begin{tabular}{llll}
\multicolumn{4}{c}{ Pasar Saham Syariah } \\
\hline R-squared & $\mathbf{0 . 4 1 8 1 6 2}$ & Mean dependent var & 0.007042 \\
\hline Adjusted R-squared & 0.384809 & S.D. dependent var & 0.061972 \\
\hline S.E. of regression & 0.048607 & Akaike info criterion & -3.152086 \\
\hline Sum squared resid & 0.370935 & Schwarz criterion & -2.965380 \\
\hline Log likelihood & 273.1992 & Hannan-Quinn criter. & -3.076306 \\
\hline F-statistic & $\mathbf{1 2 . 5 3 7 1 9}$ & Durbin-Watson stat & 1.981125
\end{tabular}

Prob(F-statistic) 0.000000

Catatan: ${ }^{* * *} ; * * *$ adalah stasioner pada $\alpha=1 \%, 5 \%, 10 \%$

Sumber: Hasil Data Diolah Eviews 10 
Tabel 6 dapat diinterpretasikan uji kointegrasi baik pasar saham syariah maupun konvensional. Pasar saham syariah (JII) dengan nilai F-hitung adalah 32.50409. Nilai F-hitung melebihi nilai I (0) pada $\alpha=1 \%$. Dari uji kointegrasi tersebut dapat disimpulkan bahwa variabel independen (BI-rate, Inflasi, LJUB, IPI dan Kurs) berhubungan dalam kondisi jangka panjang dengan variabel dependen (VJII). Nilai Fhitung melebihi nilai I (0) pada $\alpha=1 \%$. Dari uji kointegrasi tersebut dapat disimpulkan bahwa variabel independen (BI-rate, Inflasi, LUB, IPI dan Kurs) berhubungan dalam kondisi jangka panjang dengan variabel dependen (VJII). Dengan begitu dapat menilai bahwa volatilitas pasar saham baik syariah maupun konvensional memiliki hubungan jangka pendek dan jangka panjang dengan variabel ekonomi makro.

Tabel 6. Uji Kointegritasi (Bound Test)

\begin{tabular}{lcccc}
\hline \multicolumn{4}{c}{ Pasar Saham Syariah } \\
\hline \multirow{4}{*}{ Test Statistics } & Value & $\boldsymbol{\alpha}$ & $\mathrm{I}(\mathbf{0})$ & $\mathrm{I}(\mathbf{1})$ \\
F-statistic & 32.50409 & $10 \%$ & 2.08 & 3 \\
$\mathrm{~K}$ & 5 & $5 \%$ & 2.39 & 3.38 \\
& & $2.5 \%$ & 2.7 & 3.73 \\
& & $1 \%$ & 3.06 & 4.15 \\
\hline
\end{tabular}

Sumber: Hasil Data Diolah Eviews 10

Pada Tabel 7 pasar saham syariah memiliki $\mathrm{R}^{2}$ sebesar (0.617129) mengartikan bahwa variabel independen mampu menjelaskan pasar saham syariah sebesar 61,71 \% sedangkan sisanya 38,29\% dijelaskan oleh variabel di luar model.

Tabel 7. Estimasi Jangka Pendek: Model ECM

\begin{tabular}{llrr}
\hline \multicolumn{1}{c}{ Variable } & \multicolumn{1}{c}{ Coefficient } & \multicolumn{1}{c}{ Std. Error } & \multicolumn{1}{c}{ t-Statistic } \\
\hline \multicolumn{4}{c}{ Pasar Saham Syariah } \\
\hline D(BIRATE) & $-0.037623^{* *}$ & 0.017815 & -2.111921 \\
D(IPI) & $-9.05 \mathrm{E}-05$ & 0.000655 & -0.138120 \\
D(KURS) & $-9.55 \mathrm{E}-05^{* * *}$ & $1.21 \mathrm{E}-05$ & -7.902712 \\
CointEq(-1)* & $-1.005437^{* * *}$ & 0.065417 & -15.36958 \\
R-squared & 0.617129 & & \\
Durbin-Watson stat & 1.981125 & & \\
\hline
\end{tabular}

Catatan: $* * * * * ; *$ adalah stasioner pada $\alpha=1 \%, 5 \%, 10 \%$

Sumber: Hasil Data Diolah Eviews 10 
Tahapan selanjutnya estimasi kondisi jangka panjang, Tabel 8 tentang estimasi jangka panjang ARDL. Pasar saham syariah dalam estimasi jangka panjang untuk variabel independen BI Rate dan LJUB menolak $H_{0}$ dengan $\alpha=10 \%$. Variabel Inflasi tidak menolak $H_{0}$ dengan $\alpha=1 \%$ tentunya sesuai dengan hipotesis yaitu variabel Inflasi memengaruhi pasar saham syariah (indeks JII) secara negatif dan signifikan. Variabel IPI tidak menolak $H_{0}$ dengan $\alpha=5 \%$ dengan koefisien negatif dan signifikan yang berbeda dengan hipotesis. Variabel Kurs tidak menolak $H_{0}$ dengan $\alpha=10 \%$. Hasil ini sesuai dengan hipotesis penelitian yaitu variabel Kurs mempunyai pengaruh negatif dan signifikan terhadap return harga saham Jakarta Islamic Index (JII).

Tabel 8. Estimasi Jangka Panjang

\begin{tabular}{llll}
\hline Variabel & \multicolumn{1}{c}{ Coefficient } & \multicolumn{1}{c}{ Std.error } & t-statistic \\
\hline \multicolumn{3}{c}{ Pasar saham Syariah } \\
\hline BIRATE & 0.002879 & 0.005630 & 0.511393 \\
INFLASI & $-0.006532^{* * *}$ & 0.002470 & -2.644821 \\
IPI & $-0.001298^{* *}$ & 0.000548 & -2.369883 \\
KURS & $1.22 \mathrm{E}-05^{*}$ & $7.13 \mathrm{E}-06$ & 1.717466 \\
LJUB & -0.051253 & 0.031933 & -1.605024 \\
C & $0.825442^{*}$ & 0.479796 & 1.720403 \\
\hline
\end{tabular}

Catatan: $* * * * * ; *$ adalah stasioner pada $\alpha=1 \%, 5 \%, 10 \%$

\section{Interprestasi dari Pasar Saham Syariah (JII)}

$$
\begin{aligned}
E C= & \text { VJII }-(0.0029 * \text { BIRATE }-0.0065 * \text { INFLASI }-0.0013 * I P I+0.0000 * \text { KURS } \\
& -0.0513 * \text { LJUB }+0.8254)
\end{aligned}
$$

Estimasi jangka pendek pada Tabel 7 dalam pasar saham pada variabel BI Rate berpengaruh negatif dan signifikan pada $\alpha=5 \%$ terhadap pasar saham syariah. Selanjutnya untuk variabel kurs berpengaruh positif dan signifikan pada $\alpha=1 \%$ terhadap pasar saham syariah. Variabel BI Rate dan kurs memiliki pengaruh terhadap pasar saham syariah dalam jangka pendek. Perubahan kurs yang melemah akan memberikan dampak yang negatif terhadap pasar modal khususnya saham yang di mana akan memberikan dampak juga terhadap pasar ekuitas yang tidak menarik lagi untuk para investor. Perubahan suku bunga (BI Rate) yang terlalu tinggi berpengaruh negatif pada pasar saham syariah karena, suku bunga yang tinggi menyebabkan para investor menjual sahamnya dan beralih berinvestasi untuk menabung maupun dalam bentuk tabungan deposito. Sedangkan variabel IPI tidak berpengaruh signifikan terhadap pasar saham syariah dan pasar saham konvensional.

Estimasi jangka panjang variabel Inflasi dan variabel IPI memiliki pengaruh terhadap pasar saham syariah. Pasar saham syariah, variabel inflasi berpengaruh negatif dan signifikan pada $\alpha=1 \%$ dan variabel IPI berpengaruh negatif dan signifikan pada $\alpha=5 \%$. Indeks produksi industri dan harga saham berhubungan positif karena kenaikan IPI menyebabkan peningkatan produksi sektor industri yang berdampak pada peningkatan keuntungan industri dan korporasi. Variabel inflasi berpengaruh 
negatif pada pasar saham syariah pasalnya inflasi yang tinggi diikuti dengan peningkatan suku bunga akan menyebabkan pengurangan terhadap tingkat investasi.

Tabel 9. Pengujian Hipotesis

\begin{tabular}{|c|c|c|c|c|c|c|}
\hline & VARIABEL & BI RATE & INFLASI & IPI & JUB & KURS \\
\hline & \multicolumn{6}{|c|}{ Pasar Saham Syariah } \\
\hline \multirow{3}{*}{ VJII } & Hipotesis & $\begin{array}{l}\text { Negative } \\
\text { (signifikan) }\end{array}$ & $\begin{array}{l}\text { Negative } \\
\text { (signifikan) }\end{array}$ & $\begin{array}{c}\text { Positif } \\
\text { (signifikan) }\end{array}$ & $\begin{array}{c}\text { Positif } \\
\text { (signifikan) }\end{array}$ & $\begin{array}{l}\text { Negative } \\
\text { (signifikan) }\end{array}$ \\
\hline & Hasil & 0.040518 & -0.006567 & -0.001214 & -0.051532 & $-9.55 E-05$ \\
\hline & & $(0.0567)$ & (0.0100) & (0.0999) & (0.1070) & $(0.0000)$ \\
\hline
\end{tabular}

Sumber: Hasil Olah Data Eviews 10

\section{Analisis Suku Bunga terhadap Pasar Saham Syariah}

Berdasarkan hasil pengujian estimasi ARDL pada Tabel 5, bahwa variabel suku bunga ( $\mathrm{BI}$ Rate) diperoleh hasil probabilitas ( $p$-value) sebesar $0.0567>0,05$ maka hasilnya tidak terbukti memengaruhi harga saham syariah. Variabel suku bunga memiliki kesimpulan menolak hipotesis $H_{1}$ yaitu, variabel suku bunga tidak terbukti berpengaruh negatif dan signifikan terhadap pasar saham syariah (Karyatun et al., 2021; Yusof et al., 2007).

Suku bunga dapat memberikan sinyal negatif bagi investor terhadap harga saham yang cenderung mengalihkan investasinya ke alternatif investasi lain yang memiliki tingkat pengembalian lebih stabil seperti deposito, tabungan dan obligasi (Karyatun et al., 2021; Rachmawati \& Laila, 2015). Suku bunga tidak terbukti berpengaruh terhadap pasar saham syariah ini menyoroti prinsip-prinsip Islam bahwa tingkat bunga bukanlah variabel yang signifikan dalam menjelaskan volatilitas pasar saham syariah (Yusof et al., 2007).

\section{Analisis Inflasi terhadap Pasar Saham Syariah}

Analisis inflasi terhadap pasar saham syariah berdasarkan hasil pengujian ARDL pada tabel 5, bahwa variabel inflasi diperoleh hasil probabilitas ( $p$-value) sebesar $0.0100<0,05$ dengan demikian mengartikan bahwa tidak menolak hipotesis $H_{1}$ pada variabel Inflasi yaitu, variabel inflasi terbukti berpengaruh negatif dan signifikan pada pasar saham syariah (Ash-Shiddiqy, 2019; Putra et al., n.d.; Rachmawati \& Laila, 2015; Yusuf \& Hamzah, 2014; Ash-Shiddiqy, 2019; Yusuf \& Hamzah, n.d.; Putra et al., n.d.; Rachmawati \& Laila, 2015).

Kenaikan harga secara keseluruhan dan terus menerus biasa disebut dengan inflasi. Inflasi dapat mempengaruhi kegiatan perekonomian seperti pada investasi maupun harga saham. Secara teoritis inflasi yang relatif tinggi dapat memberikan sinyal negatif bagi pemodal di pasar modal. Inflasi yang tinggi diikuti dengan suku 
bunga menyebabkan pengurangan terhadap tingkat investasi. Kebijakan moneter yang dilakukan pemerintah dalam kondisi inflasi akan mengurangi jumlah uang beredar di masyarakat dengan menaikkan suku bunga (Karyatun et al., 2021; AshShiddiqy, 2019; Ardana, 2016b; Santoso et al., 2018).

\section{Analisis Indeks Produksi Industri terhadap Pasar Saham Syariah}

Analisis indeks produksi industri terhadap pasar saham syariah menurut hasil estimasi ARDL pada Tabel 5, menghasilkan probabilitas ( $P$-value) sebesar $0.0999>$ 0.05 yang mengartikan bahwa menolak hipotesis $H_{1}$ dengan kesimpulan tidak terbukti indeks produksi industri berpengaruh positif dan signifikan pada pasar saham syariah.

Pada dasarnya variabel IPI adalah indikator dalam mengukur pertumbuhan ekonomi dengan output riil. Indeks produksi industri (IPI) merupakan indikator yang mencerminkan kondisi indeks produksi industri di suatu negara. IPI dalam pasar modal Indonesia terdiri atas pergerakan saham di BEI yang tergabung dalam suatu indeks yang dinamakan IPI. Membaiknya IPI dalam pasar modal mencerminkan kondisi ekonomi industri di negara. Secara umum peningkatan IPI juga memengaruhi indeks lainnya, terutama indeks saham (Ash-Shiddiqy, 2019).

\section{Analisis Nilai Tukar terhadap Pasar Saham Syariah}

Berdasarkan pengolahan data estimasi Autoregressive Distributed Lag pada Tabel 5, menghasilkan nilai probabilitas ( $P$-value) sebesar $0.000<0.05$ yang mengartikan bahwa tidak menolak $H_{1}$ yaitu, variabel nilai tukar (kurs) terbukti berpengaruh negatif dan signifikan terhadap pasar saham syariah. Nilai tukar (kurs) mengalami peningkatan berakibat pada penurunan return saham syariah pasalnya, kenaikan nilai tukar menyebabkan kenaikan pada biaya produksi perusahaan (Yusuf \& Hamzah, n.d.; Apriliskan Fajri et al., 2020; Wulandari, 2021).

Nilai tukar rupiah terhadap dolar termasuk salah satu indikator dalam makroekonomi (Yusuf \& Hamzah, n.d.). Perubahan kurs yang melemah memberikan dampak yang negatif terhadap pasar modal khususnya saham yang dimana memberikan dampak juga terhadap pasar ekuitas yang tidak menarik lagi untuk para investor. Hubungan antara kurs dengan return harga saham adalah negatif, melemahnya rupiah memberikan pengaruh negatif terhadap pasar ekuitas, karena menyebabkan pasar ekuitas menjadi tidak mempunyai daya tarik (Yusuf \& Hamzah, n.d.).

\section{Analisis Jumlah Uang Beredar terhadap Pasar Saham Syariah}

Berdasarkan pengolahan data menggunakan estimasi ARDL menghasilkan probabilitas ( $P$-value) sebesar $0.1070>0.05$ mengartikan bahwa hipotesis $H_{5}$ ditolak yaitu, variabel jumlah uang beredar tidak terbukti berpengaruh positif dan tidak signifikan terhadap pasar saham syariah (Yusof et al., 2007). 


\section{SIMPULAN}

Penelitian analisis tentang variabel ekonomi makro dan volatilitas pasar saham syariah menggunakan metode pertama yaitu metode Generalized Autoregressive Conditional Heteroscedasticity untuk menghitung volatilitas pada harga saham syariah. Model ini menunjukkan pergerakan pasar saham JII dipengaruhi oleh besarnya volatilitas pada dua bulan sebelumnya, dan varian harga satu bulan sebelumnya. Penelitian analisis tentang variabel ekonomi makro dan volatilitas pasar saham syariah menggunakan metode Auto-Regressive Distributed Lag (ARDL). Hasil penelitian ini menyatakan bahwa variabel BI Rate yang tidak berpengaruh pada pasar saham JII pada taraf $\alpha=5 \%$ yang tentunya sesuai dengan prinsip syariah serta kepatuhan syariah. Variabel yang memengaruhi pasar saham syariah dalam jangka pendek adalah variabel BI Rate dan kurs. Variabel BI Rate dan kurs hanya memengaruhi variabel JII pada jangka pendek. Sedangkan variabel yang memengaruhi Jakarta Islamic Index (JII) dalam jangka panjang adalah variabel inflasi dan IPI yang dapat digunakan dalam menstabilkan volatilitas return harga saham syariah dalam jangka panjang.

Berdasarkan hasil penelitian ini, penulis memberikan dukungan lebih lanjut bahwa menstabilkan suku bunga tidak akan berdampak signifikan pada volatilitas pasar saham syariah. Lebih lanjut untuk pengembangan penelitian selanjutnya, direkomendasikan untuk menggunakan variabel lain dalam pengukuran makro ekonomi, serta menggunakan teknis perhitungan dan model analisis lain untuk melakukan kajian yang lebih komprehensif.

\section{DAFTAR PUSTAKA}

Amanah, N. K., Purwanto, B., \& Ermawati, W. J. (2019). Apakah Saham Berlabel Syari'ah Memenuhi Kepatuhan dan Prinsip Moral Islam? Does the Sharia Labeled Stock Fulfill Islamic Moral Compliance and Principles? (Case Study: Indonesian Islamic Capital Market). Jurnal Manajemen Dan Organisasi, 10(2), 112-117.

Apriliskan Fajri, W., Alliv Nurdiana, D., \& Rusgianto, S. (2020). Devita Alliv Nurdiana,

\& Sulistya Rusgianto. Journal of Islamic Eco-Nomics Lariba, 6, 1-18. https://doi.org/10.20885/jielariba.vol6.iss2.art5

Ardana, Y. (2016). ANALISIS PENGARUH VARIABEL MAKROEKONOMI TERHADAP INDEKS SAHAM SYARIAH INDONESIA: PERIODE MEI 2011-SEPTEMBER 2015 DENGAN MODEL ECM (Vol. 13, Issue 1).

Ash-Shiddiqy, M. (2019). PENGARUH INDEKS PRODUKSI INDUSTRI (IPI), SERTIFIKAT BANK INDONESIA SYARIAH (SBIS), INFLASI DAN NILAI TUKAR TERHADAP INDEKS SAHAM SYARIAH INDONESIA (PERIODE 2012-2018) (Vol. 3, Issue 1). Januari-Juni. Ash-Shidiq, H., \& Setiawan, A. B. (2015). ANALISIS PENGARUH SUKU BUNGA SBI, UANG BEREDAR, INFLASI DAN NILAI TUKAR TERHADAP INDEKS HARGA SAHAM JAKARTA ISLAMIC INDEX (JII) PERIODE 2009-2014. In Jurnal Ekonomi dan Perbankan Syariah (Vol. 3, Issue 2). www.idx.co.id 
Inflasi, P., \& Bunga, S. (n.d.). Kurs, dan Pertumbuhan PDB Terhadap Indeks Harga Saham Gabungan-Suramaya Suci Kewal.

Karim, A., Jabar, A., \& Cahyadi, I. F. (2020). ) Pengaruh Exchange Rate, Inflasi, Risiko Sistematis Dan BI Rate Terhadap Return Saham Syariah Di Jakarta Islamic Index (JII) Periode. 4(1).

Kartika, A., Kendeng, J. v, \& Ngisor, B. (2010). Volatilitas Harga Saham di Indonesia dan Malaysia (Vol. 12, Issue 1).

Karyatun, S., Waluyo, T., Muis, M., \& Munir, A. R. (2021). The Islamic Stock Market and Macroeconomic Relationship. In PSYCHOLOGY AND EDUCATION (Vol. 58, Issue 1). www.psychologyandeducation.net

Khan, J. (2018). The Impact of Macroeconomic Variables on Stock Prices: A Case Study of Karachi Stock Exchange. www.iiste.org

Putra, U., Yptk, l., \& Pratiwi, N. (n.d.). PENGARUH TINGKAT SUKU BUNGA, KURS DAN INFLASI TERHADAP JAKARTA ISLAMIC INDEX (JII) SIGIT SANJAYA.

Rachmawati, M., \& Laila, N. (2015). rahmawati. FAKTOR MAKROEKONOMI YANG MEMPENGARUHI PERGERAKAN HARGA SAHAM PADA INDEKS SAHAM SYARIAH INDONESIA (ISSI) DI BURSA EFEK INDONESIA (BEI) 1, Vol.2 No. 11.

Santoso, H., Islam, E., Tinggi Ilmu Ekonomi AAS, S., \& Mursito Wisnu, A. (2018). Proceeding Seminar Nasional \& Call For Papers 124 Surakarta.

Taufiq, M., Batista, \&, \& Kefi, S. (n.d.). PENGARUH INFLASI, BI RATE DAN KURS TERHADAP INDEKS HARGA SAHAM GABUNGAN.

Widarjono, A. (2020). Does the Volatility of Macroeconomic Variables Depress The Profitability of Islamic Banking? JEJAK, 13(1), 30-42. https://doi.org/10.15294/jejak.v13i1.19460

Wulandari, C. (2021). PERKEMBANGAN SAHAM-SAHAM SYARIAH (JII) DAN FAKTORFAKTOR YANG MEMPENGARUHINYADisusun sebagai salah satu syarat menyelesaikan Program Studi Strata I pada Jurusan Ekonomi dan BisnisOleh :CANDRA WULANDARIB 300160007ILMU EKONOMI STUDI PEMBANGUNANFAKULTAS EKONOMI DAN BISNISUNIVERSITAS MUHAMMADIYAH SURAKARTA2020.

Yusof, R. M., Shabri, M., \& Majid, A. (2007). Stock Market Volatility Transmission in Malaysia: Islamic Versus Conventional Stock Market. 20(2), 17-35.

Yusuf, A. A., \& Hamzah, A. (2014). PENGARUH INFLASI, SUKU BUNGA, NILAI TUKAR/KURS, DAN IHSG TERHADAP HARGA SAHAM SYARIAH PENDEKATAN ERROR CORRECTION MODEL (Penelitian Pada PT Astra Agro Lestari Tbk di Jakarta Islamic Index) Periode 2006.1 sd 2013.12.

Zakaria, Z. (2012). Empirical evidence on the relationship between stock market volatility and macroeconomic volatility in Malaysia Validating the micro determinants of export performance model for Halal food and beverages industries in Malaysia View project marketing strategy for halal market View project. https://www.researchgate.net/publication/310613721 